\title{
Dermatitis, branchitis and mortality in empire gudgeon Hypseleotris compressa exposed naturally to runoff from acid sulfate soils
}

\author{
R. B. Callinan ${ }^{1}$, J. Sammut ${ }^{3, *}$, G. C. Fraser ${ }^{2}$ \\ ${ }^{1}$ NSW Fisheries, Aquatic Animal Health Unit, and ${ }^{2}$ NSW Agriculture, Regional Veterinary Laboratory, Wollongbar, \\ New South Wales 2477, Australia \\ ${ }^{3}$ Geography, The University of New South Wales, Sydney, New South Wales 2052, Australia
}

\begin{abstract}
Severe dermatitis and branchitis are described in a wild population of empire gudgeon Hypseleotris compressa, an Australian eleotrid, exposed naturally to runoff from acid sulfate soils (ASS) in a drained estuarine embayment in eastern Australia. After at least $2 \mathrm{~d}$ exposure to $\mathrm{pH}<4$, and up to $7 \mathrm{~d}$ exposure to $\mathrm{pH}<6$, approximately $50 \%$ of the fish sampled had moderate to severe diffuse epidermal hyperplasia, usually at scale margins, and scattered areas of moderate to severe, focal to locally extensive, subacute, necrotising dermatitis. Saprolegnia spp. had invaded epidermis in some inflamed areas. In gills, there was moderate to severe hyperplasia and necrosis of secondary lamellar epithelium, with fusion of adjacent secondary lamellae. Inorganic monomeric aluminium and calcium concentrations in water at the site during the event were 27.7 and $16.6 \mathrm{mg} \mathrm{l}^{-1}$, respectively. Large numbers of empire gudgeons at the study site had died after at least $8 \mathrm{~d}$ exposure to $\mathrm{pH}<4$, and up to $13 \mathrm{~d}$ exposure to $\mathrm{pH}<6$. These findings provide clear evidence that acidification of estuarine systems by runoff from ASS has deleterious effects on aquatic biota. Furthermore, study findings suggest a mechanism whereby lesions of epizootic ulcerative syndrome (EUS) may be initiated in estuarine fishes by a combination of sublethal exposure to ASS runoff and Aphanomyces invadans infection, a suggestion consistent with the geographic and temporal distribution of EUS outbreaks in Australian estuaries.
\end{abstract}

KEY WORDS: Dermatitis $\cdot$ Mortality $\cdot$ Branchitis $\cdot$ Fish $\cdot$ Acid sulfate soils $\cdot$ Saprolegniasis $\cdot$ Epizootic ulcerative syndrome $\cdot$ EUS

Resale or republication not permitted without written consent of the publisher

\section{INTRODUCTION}

Although fish may be injured by exposure to low $\mathrm{pH}$ alone (McDonald 1983), high concentrations of inorganic monomeric aluminium are considered to be the primary cause of injury and death in fish exposed naturally to acidified water (Driscoll et al. 1980). Fish kills in river systems receiving runoff from acid sulfate soil (ASS) areas have been reported from Malaysia (Dunn 1965) and northern and eastern Australia (Brown et al. 1983, Noller \& Cusbert 1985, Sammut et al. 1995). ASS forms when pyrite $\left(\mathrm{FeS}_{2}\right)$, exposed in sulfidic subsoils by falling water tables during dry periods, reacts with atmospheric oxygen to form sulfuric acid. Subsequently, both soil and groundwater become progressively acidified and high concentrations of inorganic monomeric aluminium and other ions are released into groundwater from soil particles. Fish kills in ASS areas typically occur when fish are unable to escape the high concentrations of sulfuric acid and inorganic monomeric aluminium flushed into previously circumneutral sites after rain events (Willet et al. 1993, Sammut et al. 1995).

Fish exposed to acidified water may develop lesions in gills and skin, as well as disturbances to ionoregulatory, acid-base or respiratory mechanisms. The nature and severity of these changes depend on a combination of factors, including $\mathrm{pH}$, temperature, and concentrations of organic matter, aluminium, calcium and other metals in the water, as well as fish species and intraspecific strains, duration and previous history of ex- 
posure (Daye \& Garside 1980, Freda \& McDonald 1988, Playle et al. 1989, Mount et al. 1990, Witters et al. 1990, Norrgren et al. 1991, Poleo et al. 1991, Galle \& Montoroi 1993). Gill lesions, typically including lamellar epithelial hyperplasia and fusion of secondary lamellae, are common in fish exposed naturally or experimentally to acidified water (Daye \& Garside 1976, Linnenbach et al. 1987, Dietrich \& Schlatter 1989, Norrgren et al. 1991). Mild skin lesions, including increased secretion of mucus, cutaneous goblet cell hypertrophy and/or hyperplasia, as well as more severe skin lesions, including epidermal necrosis and sloughing, have also been described in fish exposed experimentally to acidified water (Daye \& Garside 1976, Tandjung et al. 1982, Segner et al. 1988, Ingersoll et al. 1990b, Iger \& Wendelaar Bonga 1994). We have found no reports of skin lesions in naturally exposed fish.

In this paper we describe severe dermatitis with opportunist mycotic involvement, branchitis and mortality in a wild population of empire gudgeon Hypseleotris compressa, an Australian eleotrid, exposed naturally to acidified runoff from ASS.

\section{MATERIALS AND METHODS}

As part of a study examining possible relationships between ASS runoff and deleterious effects on aquatic biota, water quality was monitored during 1993 at selected sites in Tuckean Swamp, a 4000 ha Holocene-age, infilled estuarine embayment on the lower Richmond River in eastern Australia. The swamp contains large areas of ASS (Sammut et al. 1996).

Study site. Tuckean Nature Reserve (TNR) drain (a trapezoid, open ditch drain 10 to $20 \mathrm{~m}$ wide, $1.5 \mathrm{~m}$ deep and $2.5 \mathrm{~km}$ long) is part of a network of drains within Tuckean Swamp. The empire gudgeon Hypseleotris compressa, the most common fish species in the swamp, is the only fish species observed in the drain. Siltation in the headwater reach and lower limit of TNR drain prevents entry and exit of fish, except under flood conditions. The $\mathrm{pH}$ of ASS along TNR drain and in the adjacent floodplain is normally less than 3.5, and intense rainfall events can acidify TNR drain water via immediate drain-bank runoff and displaced acidic groundwater (Sammut et al. 1996). Stratification of water (Sammut et al. 1994) has not been observed in the drain.
Rainfall. Daily rainfall within Tuckean Swamp was recorded at a location $5 \mathrm{~km}$ from the study site in the months prior to, during and following the disease event.

Water quality. Electrical conductivity (EC), dissolved oxygen concentration, $\mathrm{pH}$ and temperature were measured by meter at the study site at irregular intervals between April and August 1993. EC was measured using Model AS 302 (Activon Scientific Products). Remaining variables were measured using a Horiba U10 Water Quality Checker (Australian Scientific). On 20 July, a water sample was collected for elemental analysis. A grab sample was collected and pressure filtered in the field through a $0.45 \mu \mathrm{m}$ Millipore HA cellulose nitrate filter. The filtrate was chilled to $4^{\circ} \mathrm{C}$ during transport, and held at $-20^{\circ} \mathrm{C}$ until analysed. Concentrations of major elements, chloride and sulfate, were determined using inductively coupled atomic excitation spectroscopy, a Corning 926 chloride

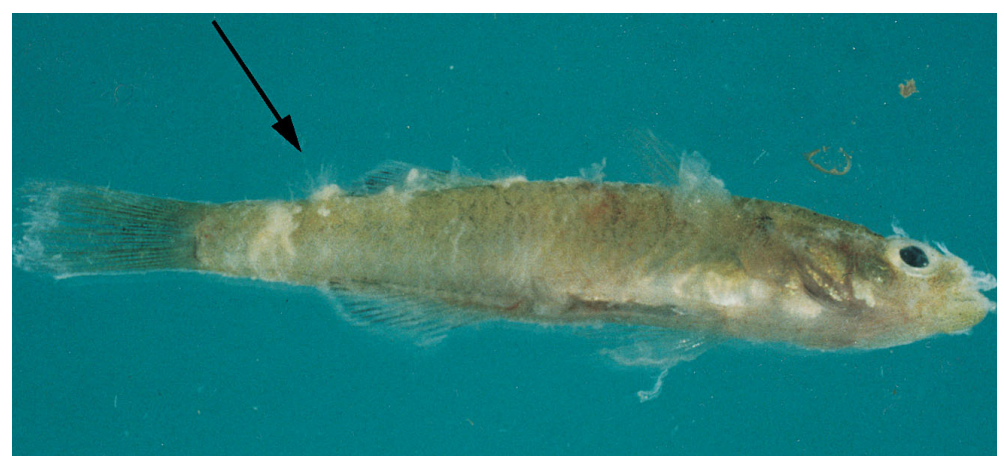

Fig. 1. Hypseleotris compressa. Empire gudgeon collected from Tuckean Nature Reserve drain during the acidification event. Numerous white flecks and tags, as well as mycelial masses (arrow), are present on the skin surface

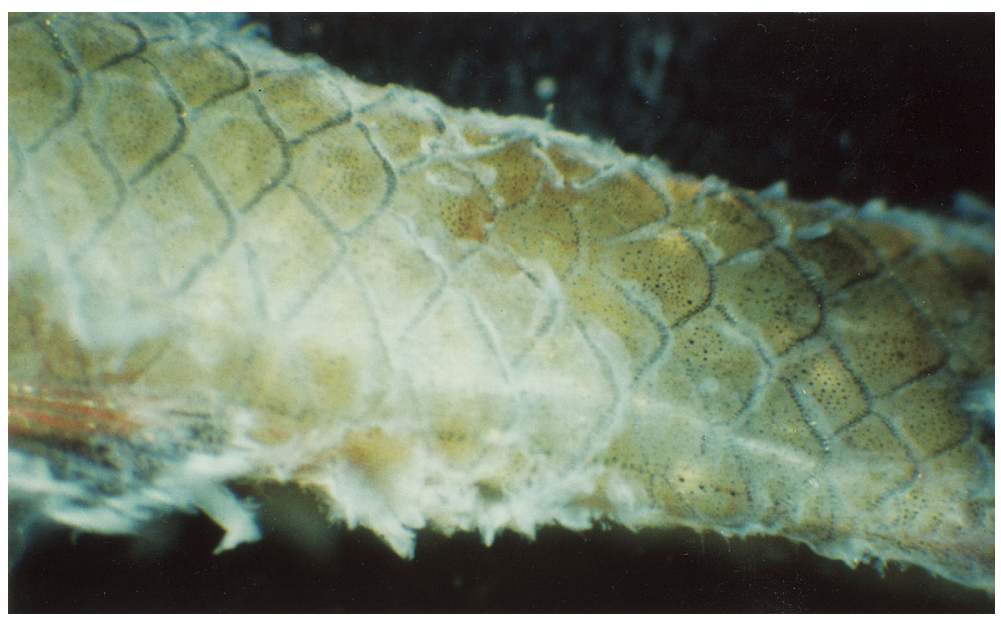

Fig. 2. Hypseleotris compressa. Close-up view showing the white flecks and tags on the skin of an empire gudgeon collected from Tuckean Nature Reserve drain during the acidification event. Note the pallor commonly present on skin at the posterior margins of the scales 
analyser, and the barium sulfate method (American Public Health Association 1992), respectively.

Fish. Male and female empire gudgeons were collected from the field study site, where water was acidified, as described below in 'Results'. To enable comparative assessment of tissue changes associated with exposure to acidified water, male and female empire gudgeons, being held in circumneutral water, were obtained from an ornamental fish supplier.

Pathology. Fish for histopathological examination were killed by severing the spinal cord at the level of the operculum. The body cavity was then opened, and fish immediately placed in 10\% neutral buffered formalin. After fixation, they were decalcified using Gooding and Stewart's fluid (Culling 1974). Serial cross sectional blocks and/or sagittal sectional blocks approximately $3 \mathrm{~mm}$ thick were embedded in paraffin wax, sectioned at $4 \mu \mathrm{m}$ and stained with haematoxylin and eosin (H\&E), Gomori methenamine silver and H\&E, PAS or alcian blue.

Mycology. By use of sterile instruments, mycelial tufts were removed from the skin of recently killed fish, dipped in a solution of penicillin $\left(132 \mathrm{mg} \mathrm{ml}^{-1}\right)$ and oxolinic acid (132 mg ml${ }^{-1}$ ) and inoculated onto glucose yeast agar (GYA) (Dykstra et al. 1986) in a laminar flow cabinet. Plates were then sealed with tape, incubated on the bench (approximately $22^{\circ} \mathrm{C}$ ) and examined daily. Growing hyphal tips, taken from the edges of representative oomycete colonies, were then inoculated onto fresh GYA. Isolates were submitted to a specialist laboratory for identification.

\section{RESULTS}

\section{Field observations}

In the 6 wk prior to and including 20 July 1993, a population of several hundred empire gudgeons was observed weekly at the water quality monitoring site in TNR drain. During this period, the fish appeared clinically normal and were seen feeding. On 21 July, approximately half the fish had numerous fine white flecks and tags diffusely scattered over the body surface (Figs. $1 \& 2$ ). Of these affected fish, approximately $20 \%$ had white cotton-wool-like tufts consistent with oomycete hyphae at 1 or more skin sites. On 22 July, the appearance and prevalence of skin lesions remained as above, and small numbers of dead fish were present at the edges of the drain. Approximately 50 live fish were collected in a trap for laboratory examination. On 27 July, large numbers of dead fish were present on the surface and live fish were no longer visible in the water column. No flow was evident in the drain during the observation period.

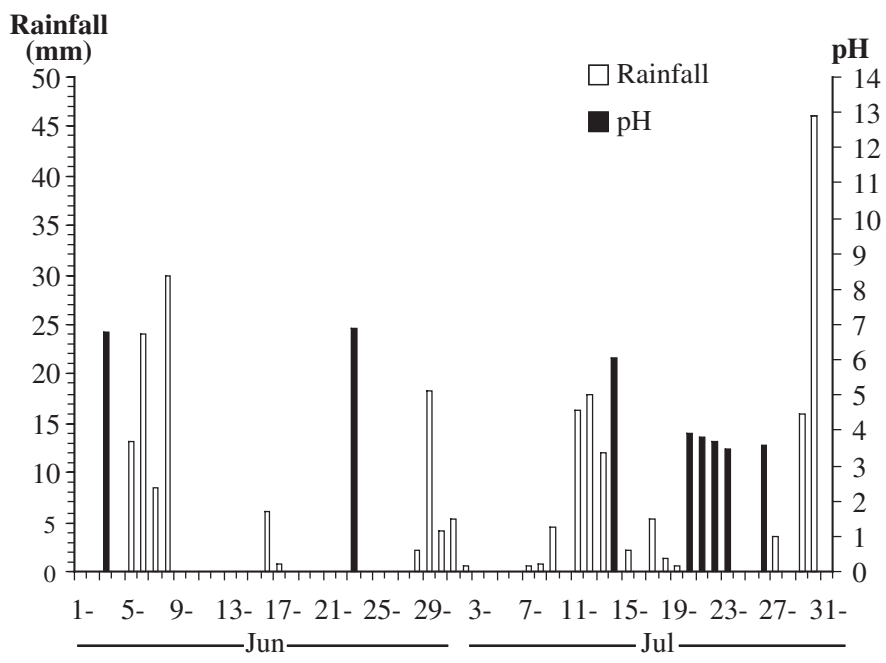

Fig. 3. Daily rainfall in Tuckean Swamp and $\mathrm{pH}$ in Tuckean Nature Reserve drain prior to, during and following the disease event

\section{Rainfall}

Rainfall for the period 1 June to 31 July is shown in Fig. 3. Total rainfall for the periods 11 to 15 July and 16 to 21 July was 57 and $10 \mathrm{~mm}$, respectively.

\section{Water quality}

Electrical conductivity of TNR drain water increased substantially between 23 June and 14 July, while pH fell from circumneutral to acidic values in the period 14 to 20 July (Table 1). In the water sample collected on

Table 1. Water quality measurements at the Tuckean Nature Reserve drain site prior to, during and following the disease event. ND: not determined

\begin{tabular}{|lcccc|}
\hline $\begin{array}{l}\text { Date } \\
(1993)\end{array}$ & $\mathrm{pH}$ & $\begin{array}{c}\text { Electrical } \\
\text { conductivity } \\
\left(\mathrm{mS} \mathrm{cm}^{-1}\right)\end{array}$ & $\begin{array}{c}\text { Dissolved oxygen } \\
\text { concentration } \\
\left(\mathrm{mg} \mathrm{l}^{-1}\right)\end{array}$ & $\begin{array}{c}\text { Temp. } \\
\left({ }^{\circ} \mathrm{C}\right)\end{array}$ \\
\hline 22 Apr & 7.0 & 117 & $\mathrm{ND}$ & $\mathrm{ND}$ \\
30 Apr & 6.5 & 194 & $\mathrm{ND}$ & $\mathrm{ND}$ \\
19 May & 6.7 & 200 & $\mathrm{ND}$ & $\mathrm{ND}$ \\
3 Jun & 6.8 & 186 & $\mathrm{ND}$ & $\mathrm{ND}$ \\
23 Jun & 6.9 & 205 & $\mathrm{ND}$ & $\mathrm{ND}$ \\
14 Jul & 6.0 & 1330 & 5.4 & 17.2 \\
20 Jul & 3.9 & 1520 & 4.4 & 18.3 \\
21 Jul & 3.8 & 1590 & 4.1 & 17.8 \\
22 Jul & 3.7 & 1570 & 4.9 & 16.0 \\
23 Jul & 3.5 & 1830 & 5.2 & 16.8 \\
26 Jul & 3.6 & 1390 & 4.9 & 21.5 \\
18 Aug & 3.4 & 1860 & 4.1 & 13.9 \\
20 Aug & 3.8 & 1670 & 3.8 & 14.8 \\
\hline
\end{tabular}


20 July, concentrations of monomeric aluminium, calcium, chloride, sulfate, total filtered iron and magnesium were $27.7,16.6,240,282,2.1$ and $25.6 \mathrm{mg} \mathrm{l}^{-1}$ respectively. Dissolved oxygen concentrations and water temperatures in the drain between 14 July and 20 August remained within limits generally consistent with fish health (Table 1).

\section{Histopathology}

Changes were similar in the 5 female and 3 male fish examined. By comparison with skin from putatively normal male and female fish held in circumneutral water (Fig. 4), there was severe focal epidermal hyperplasia, usually most pronounced at scale margins, involving most of the scaled body surface. Cells in the middle layers of hyperplastic epidermis were often ballooned, whereas those in the superficial layers had irregular margins and were often necrotic and sloughing (Fig. 5). In addition, areas of mild to severe, focal to locally extensive subacute dermatitis occurred irregularly over the body surface. Degeneration, necrosis and sloughing of epidermal cells, vascular congestion, and mononuclear cell infiltration were present in these areas (Fig. 6). Moderate numbers of nonseptate, sparsely branching hyphae 5 to $10 \mu \mathrm{m}$ in diameter were present within necrotic epidermis, but not underlying tissues, in some of these areas. Mucous cells, as demonstrated by alcian blue or PAS staining, were present in low to moderate numbers in epidermis of normal fish, but were visible only rarely in acid-exposed fish.

There was moderate to severe subacute branchitis, with diffuse congestion of lamellar vessels and irregularly distributed epithelial hyperplasia with fusion of secondary lamellae (Fig. 7). No significant lesions were seen in other organs or tissues of fish examined.

\section{Mycology}

Three isolates were obtained from skin lesions on fish. Two were identified as Saprolegnia sp. and one as S. anisospora.

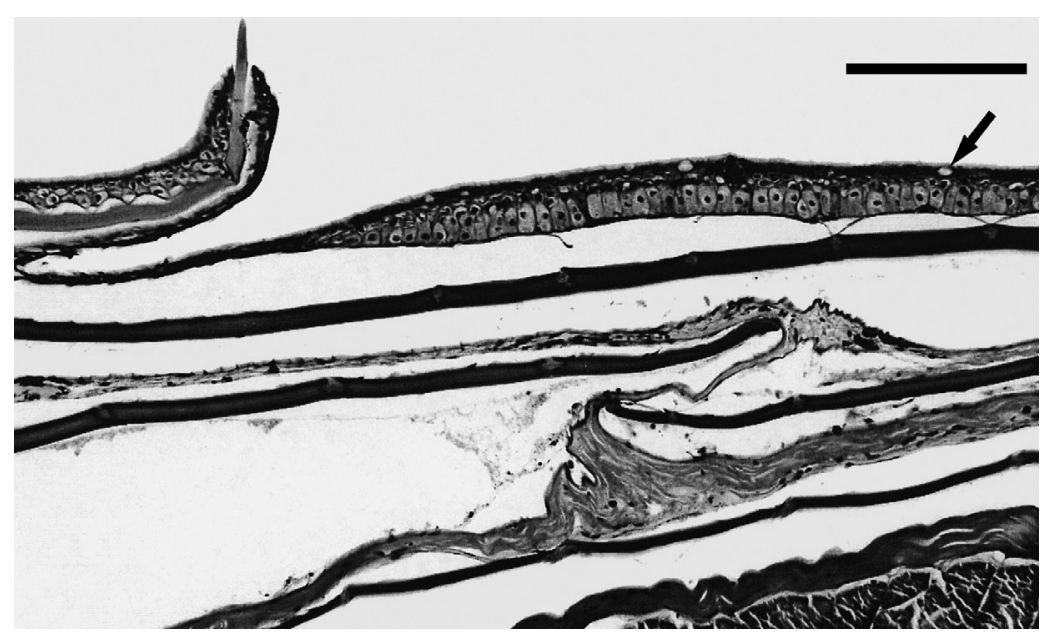

Fig. 4. Hypseleotris compressa. Skin of an empire gudgeon held in circumneutral water. Note the occasional mucous cells (arrow) at the epidermal surface. H\&E. Scale bar $=100 \mu \mathrm{m}$

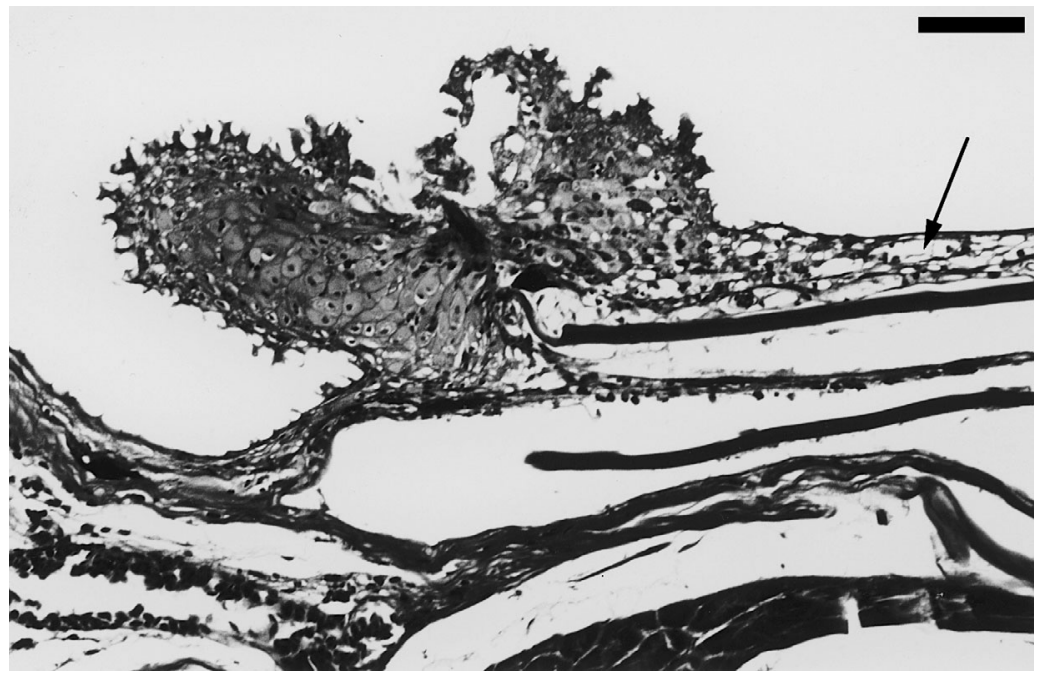

Fig. 5. Hypseleotris compressa. Skin of an empire gudgeon exposed to acidified water. There is severe focal epidermal hyperplasia at the caudal scale margin. Cells in the middle layers of the hyperplastic epidermis are ballooned, and superficial epidermal cells are necrotic and sloughing. There is vacuolar degeneration and necrosis (arrow) of epidermal cells overlying the scale surface. $\mathrm{H} \& \mathrm{E}$. Scale bar $=50 \mu \mathrm{m}$

\section{DISCUSSION}

The study findings strongly support the suggestion (Chairuddin et al. 1990, cited by Klepper et al. 1992, Sammut et al. 1995) that acidification of estuarine systems by runoff from ASS has deleterious effects on aquatic biota. Fish species vary in their ability to tolerate chronic acidification (Freda \& McDonald 1988), and short-term depressions in $\mathrm{pH}$ may cause mortalities in exposed, non-acclimated fishes (Mount et al. 1990). Empire gudgeons, which typically inhabit circumneutral freshwater or brackish streams (Allen 


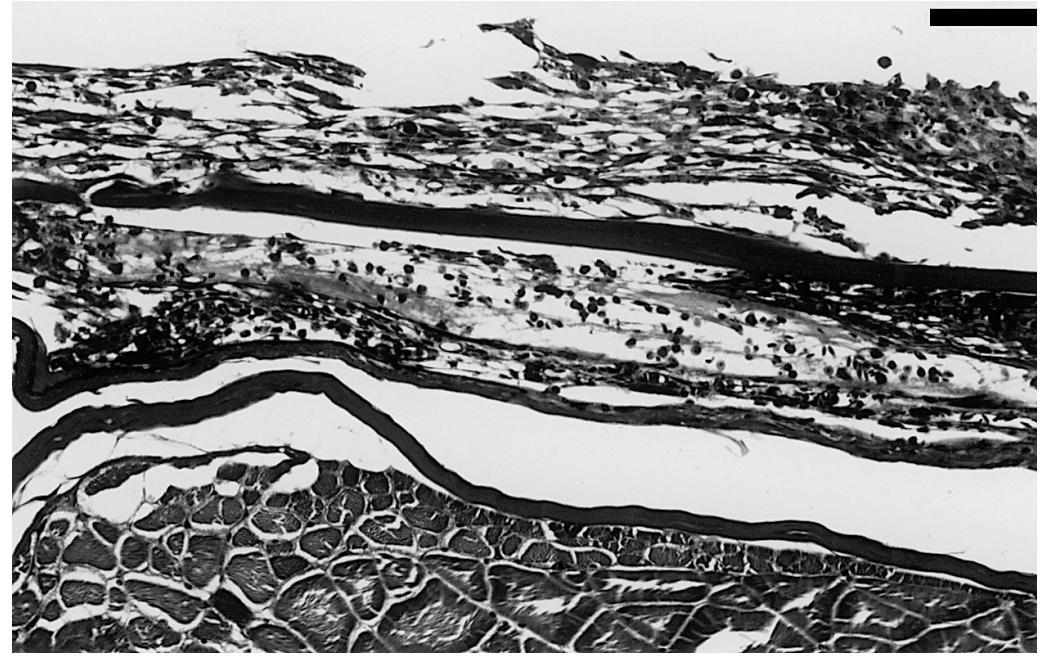

Fig. 6. Hypseleotris compressa. Locally extensive, severe, acute dermatitis in an empire gudgeon exposed to acidified water. There is spongiform and vacuolar degeneration, necrosis and sloughing of epidermal cells, with vascular congestion and mononuclear cell infiltration in stratum spongiosum. H\&E. Scale bar $=50 \mu \mathrm{m}$

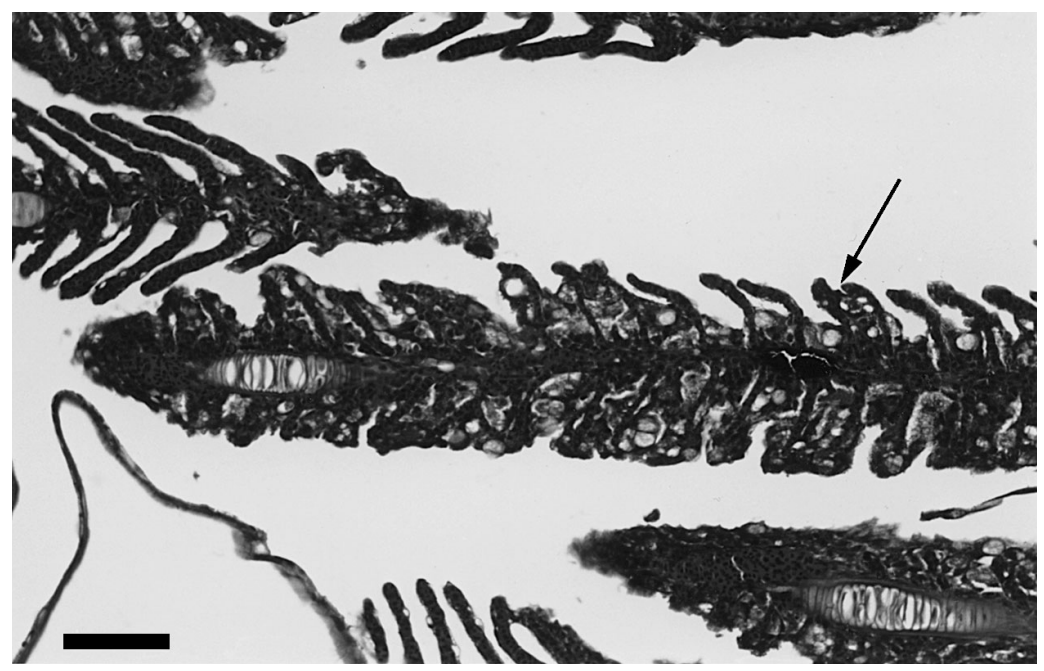

Fig. 7. Hypseleotris compressa. Gills of an empire gudgeon exposed to acidified water showing moderate to severe subacute branchitis. There is diffuse congestion of lamellar vessels and irregularly distributed epithelial hyperplasia with fusion of sec-ondary lamellae (arrow). H\&E. Scale bar $=50 \mu \mathrm{m}$

period indicated that, despite the occurrence of major rain events, acidified water was unlikely to have entered the drain. Moreover, $\mathrm{pH}$ of TNR water was in the circumneutral range on the 6 occasions it was measured during this period. Whatever the conditions in the drain during this time, they did not enable the resident empire gudgeon population to tolerate the acidification which followed the 11 to 15 July rain event. Conductivity at the study site increased substantially between 23 June and 14 July, but $\mathrm{pH}$ values on these 2 dates were in the circumneutral range, suggesting that ASS runoff was entering TNR drain by 14 July, but the buffering capacity of the water (Sammut et al. 1996) had not yet been exceeded. By 20 July, while conductivity remained high, $\mathrm{pH}$ had fallen to 3.9. These changes were almost certainly caused by ASS runoff. Typically, in coastal floodplains unaffected by pyrite oxidation, the chloride to sulfate ratio of groundwater, including that acidified by runoff from peaty soils, is approximately 7. However, when groundwater is acidified following pyrite oxidation, the added sulfate ions reduce the chloride to sulfate ratio. For TNR drain water collected on 20 July, this ratio was 0.85 , consistent with runoff from ASS (Sammut et al. 1996).

The empire gudgeons in TNR drain developed severe branchitis and dermatitis, and died within $13 \mathrm{~d}$ of continuous exposure to acidification caused by ASS runoff. Gill lesions, typically including the types seen in the current study, are common in fish exposed naturally or experimentally to acidified water (Daye \& Garside 1976, Linnen-

1989), can tolerate low pH. Populations have been recorded in a humic dune lake with pH 5.3 (Arthington et al. 1986) and a humic creek with pH 5.4 (Anonymous 1986). We have observed apparently sedentary, clinically normal empire gudgeon populations in a Tuckean Swamp drain, separate from TNR drain, in which $\mathrm{pH}$ values, caused by ASS runoff, remained between 2 and 4 for more than 2 wk.

It is likely that water in TNR drain remained circumneutral during the 3 mo prior to the July acidification. Hydrological studies in Tuckean Swamp during this bach et al. 1987, Dietrich \& Schlatter 1989, Norrgren et al. 1991). However, severe dermatitis has not previously been reported in fish exposed naturally to acidified water and not often reported in fish exposed experimentally. Daye \& Garside (1976) described epidermal necrosis and sloughing in fingerling brook trout exposed for $7 \mathrm{~d}$ to water at $\mathrm{pH} 3.2$ and 2.2. Segner et al. (1988) described epithelial sloughing in juvenile brown trout after $5 \mathrm{~d}$ exposure to progressively acidified water, beginning when $\mathrm{pH}$ fell below 6 . Concentrations of inorganic monomeric aluminium in water 
used in either of these studies were not stated. Tandjung et al. (1982) reported epidermal necrosis and sloughing, as well as dermal necrosis, in fingerling brook trout exposed to designated concentrations of aluminium and calcium at $\mathrm{pH}$ 5.6.

The epidermal necrosis and sloughing reported in the present study may have been caused by single or multiple toxic factors, including low $\mathrm{pH}$ and inorganic monomeric aluminium species, in TNR drain water. Calcium ions, which protect against the toxic effects of inorganic monomeric aluminium (Tandjung et al. 1982, Ingersoll et al. 1990a) were present at a relatively low concentration (16.6 $\mathrm{mg} \mathrm{l}^{-1}$ ) during the acidification event. By contrast, the inorganic monomeric aluminium concentration $\left(27.7 \mathrm{mg} \mathrm{l}^{-1}\right)$ was approximately 100 to 1000 times higher than those reported in previous experimental or natural exposures, with the exception of the 3 and $7.8 \mathrm{mg} \mathrm{l}^{-1}$ used by Tandjung et al. (1982).

Increased secretion of mucus in skin and gills was not seen on acid-exposed fish in the current study, even though this is a commonly reported initial response to exposure (Zuchelkowski et al. 1986, Ingersoll et al. 1990b, Berntssen et al. 1997, Ledy et al. 2003). Alcian blue and PAS-stained sections of skin revealed relatively fewer epidermal mucous cells in the acidexposed fish compared with normal fish, suggesting that these cells had exhausted their secretions in the several days since the acidification event.

Acidic conditions generally favour mycelial growth and zoospore production by Saprolegnia spp. (Peduzzi et al. 1991). It is likely that acidification in TNR drain favoured propagule production by Saprolegnia spp., and that opportunist propagules were able to infect acid-induced skin lesions on exposed fish.

Findings of the current study suggest a mechanism whereby epizootic ulcerative syndrome (EUS) lesions may be induced in estuarine fish. The putative causative infectious agent, Aphanomyces invadans, has limited ability to invade intact fish skin. Lesions can be induced experimentally only if zoospores or hyphae are injected intramuscularly into fish or if fish with areas of abraded skin are exposed to zoospores (Roberts et al. 1993, Callinan et al. 1995b). Outbreaks of EUS in estuarine fish in the Richmond River and elsewhere have been associated spatially with tributaries draining ASS areas and temporally with rain events (Virgona 1992, Callinan et al. 1993, 1995b, Sammut et al. 1995). We suggest that propagules of the causative Aphanomyces sp. may induce EUS lesions in susceptible fish species by invading skin lesions caused by sublethal exposure to ASS runoff. Although empire gudgeons are susceptible to EUS, the characteristic granulomatous myositis and dermatitis lesions (Callinan et al. 1995a) were not seen in the present study. The causative Aphanomyces sp. can grow vege- tatively and produce zoospores only at $\mathrm{pH}$ values greater than 5 (Hatai \& Egusa 1978, A. Thomas pers. comm.). It is therefore unlikely that fish in the drain were exposed to the Aphanomyces sp. during the acidification event.

Acknowledgements. We thank M. Priest, Biological and Chemical Research Institute, Rydalmere, for identification of Saprolegnia spp. isolates, as well as A. Thomas, Oonoonba Veterinary Laboratory, Queensland Department of Primary Industries and M. Digby, Southern Cross University, for helpful discussions. The study was supported in part by the Australian Centre for International Agricultural Research (Project 9130).

\section{LITERATURE CITED}

Allen GR (1989) Freshwater fishes of Australia. TFH Publications, Neptune City, NJ

American Public Health Association (1992) Standard methods for the examination of water and wastewater. American Public Health Association, American Works Association, Water Environment Federation, Washington, DC

Anonymous (1986) Fraser Island - freshwater habitat survey. J Aust New Guinea Fish Assoc 3:129-136

Arthington AH, Burton HB, Williams RW, Outridge PM (1986) Ecology of humic and non-humic dune lakes, Fraser Island, with emphasis on the effects of sand infilling in Lake Wabby. Aust J Mar Freshw Res 37:743-764

Berntssen $\mathrm{MH}$, Kroglund F, Rosseland BO, Wendelaar Bonga SE (1997) Responses of skin mucous cells to aluminium exposure at low $\mathrm{pH}$ in Atlantic salmon (Salmo salar) smolts. Can J Fish Aquat Sci 54:1039-1045

Brown TE, Morley AW, Sanderson NT, Tait RD (1983) Report of a large fish kill resulting from natural acid water conditions in Australia. J Fish Biol 22:335-350

Callinan RB, Fraser GC, Melville MD (1993) Seasonally recurrent fish mortalities and ulcerative disease outbreaks associated with acid sulfate soils in Australian estuaries. In: Dent DE, van Mensvoort ME (eds) Proceedings of the 4th International Symposium on Acid Sulfate Soils. ILRI Publication No. 53. International Institute for Land Reclamation and Improvement, Wageningen, p 403-410

Callinan RB, Paclibare JO, Bondad-Reantaso MG, Chin JC, Gogolewski RP (1995a) Aphanomyces species associated with epizootic ulcerative syndrome (EUS) in the Philippines and red spot disease (RSD) in Australia: preliminary comparative studies. Dis Aquat Org 21:233-238

Callinan RB, Paclibare JO, Reantaso MB, Lumanlan-Mayo SC, Fraser GC, Sammut J (1995b) EUS outbreaks in estuarine fish in Australia and the Philippines - associations with acid sulfate soils, rainfall and aphanomycetes. In: Shariff M, Arthur JR, Subasinghe RP (eds) Diseases in Asian Aquaculture II. Fish Health Section, Asian Fisheries Society, Manila, p 291-298

Culling CF (1974) Handbook of histopathological and histochemical techniques. Butterworths, London

Daye PG, Garside ET (1976) Histopathological changes in superficial tissues of brook trout, Salvelinus fontinalis (Mitchill), exposed to acute and chronic levels of $\mathrm{pH}$. Can J Zool 54:2140-2155

Daye PG, Garside ET (1980) Structural alterations in embryos and alevins of the Atlantic salmon, Salmo salar L., induced 
by continuous or short-term exposure to acidic levels of pH. Can J Zool 58:27-43

Dietrich D, Schlatter C (1989) Aluminium toxicity to rainbow trout at low pH. Aquat Toxicol 15:197-212

Driscoll CT, Baker JP, Bisogni JJ, Schofield CL (1980) Effect of aluminium speciation on fish in dilute acidified waters. Nature 284:161-164

Dunn IG (1965) Notes on mass fish death following drought in south Malaya. Malays Agric J 45:204-211

Dykstra MJ, Noga EJ, Levine JF, Moye DW, Hawkins JH (1986) Characterisation of the Aphanomyces species involved with ulcerative mycosis (UM) in menhaden. Mycologia 78:674-672

Freda J, McDonald DG (1988) Physiological correlates of interspecific variation in acid tolerance in fish. J Exp Biol 136:243-258

Galle C, Montoroi JP (1993) Ecological consequences of high aluminium content in acidified estuarine waters: the case of tilapia fishes in lower Casamance (Senegal). Acta Oecol 14:87-100

Hatai K, Egusa S (1978) Study on the pathogenic fungus of mycotic granulomatosis-II. Some of the note on the MG-fungus. Fish Pathol 13:85-89

Iger Y, Wendelaar Bonga SE (1994) Cellular responses of the skin of carp (Cyprinus carpio) exposed to acidified water. Cell Tissue Res 275:481-492

Ingersoll CG, Mount DR, Gulley DD, LaPoint TW, Bergman HL (1990a) Effects of pH, aluminium and calcium on survival and growth of brook trout embryos (Salvelinus fontinalis). Can J Fish Aquat Sci 47:1580-1592

Ingersoll CG, Sanchez DA, Meyer JS, Gulley DD, Tietge JE (1990b) Epidermal response to $\mathrm{pH}$, aluminum and calcium exposure in brook trout (Salvelinus fontinalis) fry. Can J Fish Aquat Sci 47:1616-1622

Klepper O, Chairuddin GT, Iriansayaii, Rijksen HD (1992) Water quality and the distribution of some fishes in an area of acid sulphate soils, Kalimantan, Indonesia. Hydrobiol Bull 25:217-224

Ledy K, Giamberini L, Pihan JC (2003) Mucous cell responses in gill and skin of brown trout Salmo trutta fario in acidic, aluminium-containing stream water. Dis Aquat Org 56: 235-240

Linnenbach M, Marthaler R, Gebhardt H (1987) Effects of acid water on gills and epidermis in brown trout (Salmo trutta L.) and in tadpoles of the common frog (Rana temporaria L.). Ann Soc R Zool Belg 117:365-374

McDonald DG (1983) The effects of $\mathrm{H}^{+}$upon the gills of freshwater fish. Can J Zool 61:691-703

Mount DR, Swanson MJ, Breck JE, Farag AM, Bergman HL (1990) Responses of brook trout (Salvelinus fontinalis) fry to fluctuating acid, aluminium, and low calcium exposure. Can J Fish Aquat Sci 47:1623-1630

Noller BN, Cusbert PJ (1985) Mobilisation of aluminium from a tropical floodplain and its role in natural fish kills: a conceptual model. In: Lekkas TD (ed) International Conference on Heavy Metals in the Environment, Vol 1. CEP

Editorial responsibility: Carl Schreck,

Corvallis, Oregon, USA
Consultants, Edinburgh, p 700-702

Norrgren L, Wicklund GA, Malmborg O (1991) Accumulation and effects of aluminium in the minnow (Phoxinus phoxinus L.) at different pH levels. J Fish Biol 39:833-847

Peduzzi R, Kappeli F, Turian G (1991) Repercussion de l'acidification de l'eau sur l'insurgence de la saprolegniose chez le poission. Sydowia 43:135-147

Playle CR, Goss GG, Wood CM (1989) Physiological disturbances in rainbow trout (Salmo gairderi) during acid and aluminium exposures in soft water of 2 calcium concentrations. Can J Zool 67:314-324

Poleo AB, Lydersen E, Muniz IP (1991) The influence of temperature in aqueous aluminium chemistry and survival of Atlantic salmon (Salmo salar L.) fingerlings. Aquat Toxicol 21:267-278

Roberts RJ, Willoughby LG, Chinabut S (1993) Mycotic aspects of epizootic ulcerative syndrome (EUS) of Asian fishes. J Fish Dis 16:169-183

Sammut J, White I, Melville MD (1994) Stratification in acidified coastal floodplain drains. Wetlands 13:49-64

Sammut J, Melville MD, Callinan RB, Fraser GC (1995) Estuarine acidification: impacts on aquatic biota of draining acid sulfate soils. Aust Geogr Stud 33:89-100

Sammut J, White I, Melville MD (1996) Acidification of an estuarine tributary in eastern Australia due to drainage of acid sulfate soils. Mar Freshw Res 47:669-684

Segner H, Marthaler R, Linnenbach M (1988) Growth, aluminium uptake and mucous cell morphometrics of early life stages of brown trout, Salmo trutta, in low $\mathrm{pH}$ water. Environ Biol Fishes 21:153-159

Tandjung SD, Rottiers DV, Herman RL (1982) Histopathological studies on the effects of acid stress to brook trout Salvelinus fontinalis (Mitchill) in the presence of sublethal concentrations of aluminium. In: Johnson RE (ed) Acid Rain/Fisheries, Proceedings of an International Symposium on Acid Rain and Fishery Impacts on Northeastern North America. American Fisheries Society, Bethesda, p 357

Virgona JL (1992) Environmental factors influencing the prevalence of a cutaneous ulcerative disease (red spot) in the sea mullet, Mugil cephalus L., in the Clarence River, New South Wales, Australia. J Fish Dis 15:363-387

Willett IR, Melville MD, White I (1993) Acid drainwaters from potential acid sulfate soils and their impact on estuarine ecosystems. In: Dent DE, van Mensvoort ME (eds) Proceedings of the Fourth International Symposium on Acid Sulfate Soils. ILRI Publication No. 53, International Institute for Land Reclamation and Improvement, Wageningen, p 419-425

Witters HE, van Puymbroek S, Vangenechten JH, Vanderborght OL (1990) The effect of humic substances on the toxicity of aluminium to adult rainbow trout, Onchorhynchus mykiss (Walbaum). J Fish Dis 37:43-53

Zuchelkowski EM, Lantz RC, Hinton DE (1986) Skin mucous cell response to acid stress in male and female brown bullhead catfish, Ictalurus nebulosis (Lesueur). Aquat Toxicol 8:139-148

Submitted: May 8, 2000; Accepted: April 26, 2004 Proofs received from author(s): December 3, 2004 